\title{
STIMULASI MOTORIK KASAR ANAK MELALUI KEGIATAN MENYANYI BAGI GURU-GURU PAUD DI KECAMATAN CANDUANG KABUPATEN AGAM
}

\author{
Indra Yeni ${ }^{1}$, Irdhan Epria Dharma Putra ${ }^{2}$, Vivi Anggraini ${ }^{3}$ \\ Universitas Negeri Padang \\ indrayeni@fip.unp.ac.id
}

\begin{abstract}
Abstrak
Lembaga Pendidikan Anak Usia Dini biasanya menggunakan kegiatan bernyanyi untuk pengembangan seni pada anak. Ketersediaan lagu untuk kegiatan belajar-mengajar di Pendidikan Anak Usia Dini sangat banyak. Namun karena keterbatasan guru membaca notasi lagu berdampak pada minimnya perbendaharaan lagu yang dimiliki oleh guru. Hal ini mengakibatkan tidak terstimulasinya semua aspek-aspek perkembangan pada anak melalui lagu. Salahsatunya yaitu aspek perkembangan motorik kasar. Beberapa penyebab terjadinya fenomena ini, antara lain : (1) pembelajaran lebih difokuskan kepada aspek pengembangan pada anak usia dini; (2) ketersediaan sarana dan prasarana yang tidak memadai, sesuai permasalahan yang sudah dikemukakan. Metode yang digunakan untuk menyelesaikan permasalahan diatas ini adalah melalui pemberian pelatihan pada Program Kemitraan Masyarakat (PKM) dengan judul " Pelatihan Stimulasi Motorik Kasar Anak melalui Kegiatan Menyanyi bagi Guru-Guru Pendidikan Anak Usia Dini di Kecamatan Canduang, Kabupaten Agam. Hal ini sesuai dengan kesepakatan yang telah dilakukan bersama ketua IGTKI Canduang, Kabupaten Agam. Kegiatan ini memiliki beberapa tahapan antara lain : (1) pembuatan Modul dalam menstimulasi motorik kasar anak melalui Kegiatan Menyanyi, dan (2) Melaksanakan Praktek Stimulasi motorik kasar Anak melalui Kegiatan Menyanyi bagi Guru-Guru Pendidikan Anak Usia Dini.
\end{abstract}

Kata Kunci : Stimulasi Motorik Kasar, Kegiatan Menyanyi, Anak Usia Dini

\begin{abstract}
Early Childhood Education institutions usually use singing activities for the development of art in children. The availability of songs for teaching and learning activities in Early Childhood Education is very much. However, because of the teacher's limitation in reading song notation, it has an impact on the lack of vocabulary owned by the teacher. This results in the non-stimulation of all aspects of development in children through songs. One of them is the aspect of gross motor development. Some of the causes of this phenomenon include: (1) learning is more focused on aspects of development in early childhood; (2) availability of inadequate facilities and infrastructure, according to the problems that have been raised. The method used to resolve the above problem is through the provision of training in the Community Partnership Program (PKM) with the title "Training of Childhood Motor Motor Stimulation through Singing Activities for Early Childhood Education Teachers in
\end{abstract}


Canduang District, Agam Regency. This is in accordance with an agreement made with the head of IGTKI Canduang, Agam Regency. This activity has several stages including: (1) making modules in stimulating the gross motor child through singing activities, and (2) carrying out the practice of gross motor stimulation of children through singing activities for early childhood education teachers.

Keywords: Gross Motor Stimulation, Singing Activities, Early Childhood

\section{PENDAHULUAN}

Pendidikan merupakan suatu kegiatan universal dalam kehidupan manusia. Hakikatnya pendidikan merupakan usaha manusia untuk memanusiakan manusia itu sendiri, yaitu untuk membudayakan manusia. Secara umum pendidikan adalah upaya sadar untuk membentuk pribadi anak menjadi orang dewasa yang mandiri, sebab pendidikan bertujuan untuk membelajarkan anak supaya menjadi dewasa, mandiri dan terjadi perubahan baik dalam pengetahuan, perilaku, maupun sikap.

Di samping pendidikan berlaku bagi siapa saja, pendidikan juga berlangsung seumur hidup (life long education), kalimat yang sering dikenal sejak dulu sampai sekarang, yang artinya "pendidikan sepanjang hayat". Semua itu menjelaskan bahwa pendidikan telah menjadi kebutuhan pokok manusia. Adanya konsep pendidikan seumur hidup memungkinkan seseorang mengembangkan potensi sesuai dengan kebutuhannya. Konsep pendidikan sepanjang hayat menjadi panduan dalam meninggikan harkat dan martabat manusia. Anak-anak bangsa ini tidak boleh tertinggal dengan bangsa lainnya di dunia. Oleh karena itu, pendidikan sejak dini harus ditanamkan kepada mereka.

Salah satu kebijakan pemerintah di sektor pendidikan yang mendukung pendidikan sepanjang hayat adalah diakuinya Pendidikan Anak Usia Dini (PAUD) sebagai pendidikan yang sangat mendasar dan strategis dalam pembangunan sumber daya manusia. UU No. 20 tahun 2003 tentang Sistem Pendidikan Nasional menyatakan bahwa usia anak usia dini adalah sejak lahir sampai usia 6 tahun. Anak usia tersebut dipandang memiliki karakteristik yang berbeda dengan anak usia diatasnya dan anak pada usia tersebut pada masa golden age.

Dari aspek pendidikan, stimulasi dini sangat diperlukan guna memberikan rangsangan terhadap seluruh aspek perkembangan anak, yang mencakup penanaman nilai-nilai dasar (agama dan budi pekerti), pembentukan sikap (disiplin dan kemandirian) dan pengembangan kemampuan dasar (berbahasa, motorik, kognitif , sosial emosional dan seni).

Salah satu aspek harus yang dikembangkan pada anak usia dini adalah perkembangan motorik kasar anak , Ketika anak mencapai tahapan usia tertentu, terdapat ciri yang sangat berbeda dengan usia bayi perbedaanya terletak pada penampilan, proporsi 
tubuh, berat dan panjang badan serta ketrampilan yang dimiliki. Kalau kita perhatikan, pada anak usia dini telah tampak otot-otot tubuh yang berkembang sehingga memungkinkan mereka melakukan berbagai jenis ketrampilan. Dengan bertambahnya usia perbandingan antara bagian tubuh berubah. Selain itu, letak gravitasi maikn berada bagian bawah tubuh sehingga keseimbangan ada pada tungkai bagian bawah.

Pada usia tertentu gerakan anak usia lebih terkendali dan terorganisasi dengan pola-pola seperti menegakkan tubuh dalam posisi berdiri, tangan dapat terjungkai dengan santai serta mampu melangkah dengan menggerakkan tungkai dan kaki. Pola-pola tersebut memungkinkan anak untuk memberikan respon dalam berbagai situasi yang mereka hadapi. Pada masa ini ketrampilan motorik kasar dan halus sangat pesat perkembangannya. Karena pada umumnya anak usia TK sangat aktif. Mereka memiliki penguasaan terhadap tubuhnya dan sangat menyukai kegiatan yang dilakukan sendiri. Karena otot-otot besar lebih berkembang dari pada kontrol terhadap tangan dan kaki, sehingga mereka belum bisa melakukan kegiatan yang rumit.

Sesuai Undang-Undang Republik Indonesia No. 20 Tahun 2003 tentang Sistem Pendidikan Nasional Pasal 3, yaitu "Pendidikan nasional berfungsi mengembangkan kemampuan dan membentuk watak serta peradaban bangsa yang bermartabat dalam rangka mencerdaskan kehidupan bangsa, bertujuan untuk berkembangnya potensi peserta didik agar menjadi manusia yang beriman dan bertakwa kepada Tuhan Yang Maha Esa, berakhlak mulia, sehat, berilmu, cakap, kreatif, mandiri, dan menjadi warga Negara yang demokratis serta bertanggung jawab".

Perlu ditekankan pada pernyataan bahwa pendidikan yang diberikan oleh pendidik haruslah dapat membentuk watak yang bermartabat pada anak serta mengembangkan potensi anak agar menjadi manusia yang berakhlak mulia. Dari pernyataan tersebut, sangatlah nyata bahwa harapan dengan memberikan pendidikan berupa Stimulasi yang sesuai untuk anak dalam menembangkan keterampilan motorik kasar anak.

Berdasarkan uraian di atas maka perlu adanya sebuah usaha yang terprogram dan terencana dalam meningkatkan perkembangan motorik kasar anak di usia 5-6 tahun. Peningkatan perkembangan motorik kasar anak ini dapat dilakukan dengan menggunakan strategi pembelajaran penggunaan musik (vokal/instrumen) di PAUD karena dengan menggunakan musik maka akan memberikan efek pada otak dengan cara menstimulasi intelektual dan perkembangan motorik kasar anak.. Karena musik juga salah satu ilmu pengetahuan dan seni tentang kombinasi ritmik dari nada-nada, baik vokal maupun instrumental, yang meliputi melodi dan harmoni sebagai ekspresi dari segala sesuatu yang ingin diungkapkan. 
Musik juga dapat menyeimbangkan fungsi otak kanan dan otak kiri sehingga menyeimbangkan aspek intelektual dan motorik kasaronal. Tidak hanya menyeimbangkan otak kiri dan kanan, musik juga dapat menyehatkan jiwa sebagai pendekatan belajar (terutama berhitung) dan mengajarkan sopan santun sehingga dapat menyalurkan motorik kasarnya secara positif untuk mencegah terjadinya tindak kekerasan. Dengan demikian, tidaklah berlebihan bila musik dikatakan sebagai pendidik humanis. Itulah sebabnya anak terbiasa mendapatkan pendidikan musik akan tumbuh menjadi manusia yang berpikiran logis, cerdas, kreatif, mampu mengambil keputusan, serta mempunyai empati dan berbadan sehat.

Selain kondisi umum sebagaimana dikemukakan di atas, usulan proposal Program Kemitraan Masyarakat (PKM) ini juga disusun berdasarkan kondisi mitra saat ini, sesuai dengan informasi yang dikemukakan pengurus IGTK Kecamatan Canduang Kabupaten Agam pada observasi awal, Kecamatan Canduang secara geografis berada pada Wilayah Kabupaten Agam.

Penyelenggaraan pendidikan pada jenjang usia dini dan pendidikan dasar dikelola pemerintah melalui UPTD Pendidikan Kecamatan Canduang yang berada dibawah Dinas Pendidikan Kabupaten Agam. IGTK Kecamatan Canduang menaungi 2 gugus yakni gugus Rumah gadang dan Bundo kanduang. Praktisi PAUD/Guru pada kecamatan ini memiliki latar belakang pendidikan yang variatif dimana secara umum dapat dibedakan menjadi bidang PAUD dan non-PAUD, dengan persentase jumlah yang hampir berimbang.

Satuan lembaga PAUD biasanya menggunakan kegiatan bernyanyi untuk pengembangan seni pada anak. Ketersediaan lagu untuk kegiatan belajar-mengajar di PAUD sangatlah banyak, namun karena keterbatasan guru dalam memilah dan membaca notasi lagu berdampak pada minimnya perbendaharaan lagu yang dimiliki oleh guru. Ada beberapa hal yang menyebabkan terjadinya fenomena ini, antara lain :

\section{1) Pembelajaran hanya difokuskan kepada aspek pengembangan akademik saja.}

Penyelengaraan pendidikan saat ini lebih berorientasi pada pengembangan akademik. Sedangkan Pengembangan pada aspek afektif juga psikomotor sering terabaikan sehingga hal ini berpengaruh kepada fokus guru yang lebih mengedepankan keberhasilan pembelajaran yang berorientasi kepada akademik. Kebanyakan guru masih belum memahami pentingnya pengetahuan tentang langkah-langkah mengajarkan lagu, hal ini jika dilakukan dengan benar dapat mengembangkan kemampuan motorik kasar anak. Pendidik melupakan langkah-langkah mengajarkan sebuah lagu pada anak usia dini. Pada umumnya pendidik mengajarkan secara langsung lagu 
kepada anak didik dengan pengetahuan seadanya. Kita ketahui di PAUD menggunakan pendekatan tematik. Semua yang diajarkan mengacu pada tema/subtema yang tujuannya sebagai perantara untuk memudahkan anak mempelajari segala sesuatu yang ada di sekitarnya.

Salah satu faktor penentu dalam pencapaian hasil belajar peserta didik adalah pendidiknya. Kualifikasi pendidikan yang dimiliki oleh pendidik merupakan kunci dari keberhasilan mendidik anak. Pendidik memiliki peran strategis dalam proses membelajarkan anak untuk mentransformasi pengetahuan, keterampilan, dan nilai-nilai kepada peserta didik. Prayitno (2009: 20) menyatakan pendidik perlu mengenal potensi peserta didik secara individual: bakat, minat, dan kecenderungan diri mereka masing-masing. Hal ini berguna untuk pengembangan kemampuan peserta didik yang optimal. Untuk dapat mengembangan potensi peserta didik di PAUD pendidik harus mempunyai beberapa prasyarat kompetensi dasar. Sebagaimana yang ditetapkan Depdiknas (2005) bahwa untuk menjadi seorang pendidik di PAUD diharuskan memiliki beberapa persyaratan seperti: periang, sayang terhadap anak, pandai bergaul, humoris, jujur dan penuh pengabdian. Disamping itu secara teknis pendidik diharapkan memiliki kemampuan yang "serba bisa" seperti menyanyi, menari, memainkan beberapa alat musik, menggambar dan bercerita serta mendongeng.
Kegiatan menyanyi dilakukan hanya sebatas untuk menghibur anak, dikala anak jenuh dalam proses pembelajaran tanpa menekankan pada perkembangan motorik kasar anak.

\section{2) Rendahnya pemahaman guru tentang langkah-langkah mengajarkan lagu pada AUD.}

Dasar-dasar pengajaran musik di PAUD secara teoritis anak belajar menyanyi dengan cara meniru dan pembiasaan. Hal ini dapat dilakukan dengan membangun minat anak terhadap lagu yang diajarkan berdasarkan langkah-langkah mengajarkan lagu yang sesuai. Kenyataan yang ditemui lapangan saat ini, kegiatan bernyanyi dilaksanakan sebatas sebagai alat untuk mendiamkan anak, menstabilkan suasana kelas dan menghilangkan kejenuhan anak.

Padahal suatu keharusan terhadap pendidik dalam menjalankan tugas di PAUD dalam upaya pengembangan potensi anak secara maksimal, sehingga mereka dapat tumbuh dan berkembang sesuai dengan kemampuan masing-masing. Pengembangan kemampuan dasar anak dalam berbagai bidang itu akan memberi pengaruh terhadap perkembangan anak untuk pendidikan selanjutnya terutama dengan prinsip pendidikan berkelanjutan sepanjang hayat. Sebagaimana diketahui lagu dapat mengembangkan perkembangan motorik kasar pada anak. Perkembangan motorik kasar anak perlu distimulasi sejak usia dini agar anak dapat tumbuh serta memiliki 
kesseimbangan sesuai dengan tahap perkembangannya.

\section{3) Ketersediaan Sarana dan Prasarana Tidak Memadai}

Sarana dan prasarana sangat dibutuhkan dalam menunjang kegiatan bernyanyi untuk mengembangkan beragam aspek yang ada diri anak. seperti: ruangan, alat musik, dan sarana penunjang lainnya. Elfindri (2007) menjelaskan bahwa faktor ketersediaan sarana dan prasarana merupakan faktor penentu dalam peningkatan mutu pelaksanaan pendidikan. IGTKI sebagai lembaga pengembangan kompetensi dan profesi guru lembaga PAUD berupaya menjalin kerjasama dengan stakeholder yang relevan untuk mengembangkan kompetensi guru lembaga PAUD. Salah satu upaya tersebut ialah mendukung pelaksanaan program IPTEKS bagi masyarakat yang diselenggarakan oleh perguruan tinggi sebagai kegiatan pengabdian kepada masyarakat, dalam hal ini kegiatan pelatihan untuk menstimulasi motorik kasar anak untuk guru-guru PAUD di Kecamatan Canduang Kabupaten Agam. Sehingga peran IGTKI terhadap pengembangan kompetensi guru lembaga PAUD di bidang seni sangat signifikan mendukung terciptanya proses pembelajaran seni yang aktif, kreatif, inovatif, dan efisien pada jenjang pendidikan usia dini.

Guru PAUD dipilih sebagai sasaran kegiatan ini dengan beberapa alasan. Pertama, para guru PAUD berkepentingan langsung terhadap perkembangan anak karena melalui lagu mereka akan mengembangkan aspek-aspek perkembangan anak. Kedua, diharapkan dengan adanya kegiatan pelatihan ini dapat memberikan kontribusi dalam bidang pendidikan, khususnya membantu guru menstimulasi perkembangan motorik kasar anak melalui kegiatan bernyanyi.

Kegiatan pengabdian masyarakat ini dipusatkan di dua lokasi yaitu TK Baiturrahman yang terletak di Jorong Sungai Sariak Kecamatan Canduang Kabupaten Agam. TK Darul Falah terletak di wilayah berpenduduk cukup padat, dengan tingkat anak usia sekolah yang tinggi, sedangkan TK Darul Falah berada di wilayah yang tidak begitu padat penduduk namun memiliki penduduk usia produktif. Hal ini berdampak pada kebutuhan akan pendidikan usia dini yang berkualitas pun meningkat. Akibatnya, TK Darul Falah dan TK Baiturrahman, terus berkembang dan terbuka untuk masyarakat umum. dilakukan, penyelenggaraan pendidikan di TK Darul Falah dan TK Baitrurrahman sudah baik. Hal ini ditandai dengan peningkatan jumlah siswanya per tahun.

\section{METODE PENELITIAN}

Penelitian ini menggunakan pendekatan deskriptif kualitatif. Teknik pengumpulan data adalah berupa wawancara, dokumentasi dan studi pustaka.

\section{HASIL DAN PEMBAHASAN}

Menurut Schramm (Sadiman, 1990:8); Hamalik (1989:12); dan 
Sanaky (2011:4), media pembelajaran adalah sarana pendidikan yang dapat digunakan sebagai perantara dalam proses pembelajaran untuk mempertinggi efektivitas dan efisiensi dalam mencapai tujuan pembelajaran. Tanpa bantuan media, maka materi pembelajaran sukar untuk dicerna dan dipahami oleh anak, terutama materi pembelajaran yang rumit dan kompleks. Dengan adanya media, kegiatan pembelajaran dapat lebih efektif dan efisien. Kemp dan Dayton dalam Arsyad (2007:19) mengemukakan bahwa media dapat memenuhi tiga fungsi utama apabila digunakan untuk perorangan, kelompok, atau kelompok pendengar yang besarjumlahnya, yaitu: 1) memotivasi minat anak atau tindakan; 2) menyajikan informasi; 3) memberi instruksi. Sedangkan Asyar (2011:29-35) mengatakan, fungsi media pembelajaran adalah: 1) sebagai sumber belajar; 2) fungsi semantik; 3) fungsi manipulatif; 4) fungsi fiksatif; 5) fungsi distributif; 6) fungsi psikologis. Sehingga dapat dikatakan bahwa fungsi dari media dapat memudahkan guru untuk melakukan pembelajaran dalam mengembangkan aspek perkembangan oleh guru pada saat itu.

Lagu merupakan salah satu media yang dapat digunakan sebagai media pembelajaran untuk mengembangkan berbagai potensi anak. Berbagai pesan dapat disampaikan melalui lagu dengan cara menyanyikannya dengan baik dan benar sesuai dengan notasi lagunya.

Sulit membuat definisi yang tepat dan lengkap tentang pengertian musik, karena musik dapat ditinjau dari berbagai sudut pandang. Eagle (Djohan, 2009: 36) mendefinisikan musik sebagai suara dan diam yang terorganisir melalui waktu yang mengalir (dalam ruang). Chirst dan Delone (1975: 1), mengemukakan musik sebagai rangkaian bunyi ekspresif yang dimaksud untuk membangkitkan respons manusia.

Kamien (1998: 2) mengemukakan musik adalah seni yang mendasarkan pada pengorganisasian bunyi menurut waktu. Hal yang membedakan musik dari jenis bunyi lain yaitu adanya elemen utama yang melekat pada bunyi yang bersifat musikal. Lebih jauh dijelaskan bahwa elemen tersebut ialah irama, melodi, dan harmoni. Sejalan dengan pendapat ini, Remer (Elliot, 1995) dan Jamalus (1988) mengemukakan musik dibangun oleh unsur-unsur ritme, melodi, harmoni, tekstur, dan bentuk yang

dibungkus oleh kualitas musik, yaitu unsur warna bunyi (timbre) atau warna nada dan kekuatan (volume atau intensitas) atau dinamika bunyi. Abril (2011) dalam jurnal berjudul Music, Movement, and Learning mengungkapkan bahwa gerak dan lagu dapat digunakan untuk mengembangkan atau menguatkan konsep pengetahuan, keterampilan atau pemahaman. Gerak dan lagu merupakan komponen musik yang dapat membantu siswa mengingat dan memahami konsep materi lebih cepat (Abril, 2011). Plato mengatakan bahwa musik adalah sebuah instrumen pendidikan yang 
lebih kuat daripada instrumen lainnya(Rose \& Nicholl, 2011:243).

Berdasarkan uraian di atas dapat disimpulkan bahwa musik adalah seni yang berkaitan dengan pengorganisasian bunyi dan diam menurut waktu dan bersifat musikal. Seni musik adalah cetusan ekspresi perasaan atau pikiran yang dikeluarkan secara teratur dalam bentuk bunyi. Bisa dikatakan, bunyi (suara) adalah elemen musik paling dasar. Suara musik yang baik adalah hasil interaksi dari tiga elemen, yaitu: irama, melodi, dan harmoni. Pilhofer dan Day (2007:6) mengemukakan irama (rhythm) adalah suatu pola yang teratur maupun tidak teratur di dalam musik. Sedangkan Jamalus (1988:7) mengemukakan bahwa irama adalah urutan gerak yang menjadi unsur dasar dalam seni. Dalam musik, irama terbentuk dari perpaduan bunyi tertentu dan diam dengan lama waktu atau panjang-pendeknya yang bermacammacam, membentuk pola irama yang bergerak menurut pulsa dalam ayunan birama. Mahmud (1995:11), pada irama ada pulsa, denyut, hitungan, yang berlangsung secara teratur dalam jarak waktu yang sama. Dengan demikian, dapat dikatakan bahwa irama adalah pengaturan suara dalam suatu waktu, panjang, pendek dan temponya, dan ini memberikan karakter tersendiri pada setiap musik. Kombinasi beberapa tinggi nada dan irama akan menghasilkan melodi tertentu (Yeni, 2009: 89). Selanjutnya, kombinasi yang baik antara irama dan melodi melahirkan bunyi yang harmoni.
Musik termasuk seni manusia yang paling tua. Bahkan bisa dikatakan, tidak ada sejarah peradaban manusia dilalui tanpa musik. Musik menyentuh kehidupan manusia secara menyeluruh ia adalah suatu disiplin ilmu yang melibatkan sisi sisi emosional intelektual dan fisikal. Melalui kegiatan musik seseorang bukan saja dapat mengembangkan kreatifitasnya tapi juga kepercayaan diri, sikap pengertian, kemampuan bekerja sama, kesadaran spiritual dan memiliki apresiasi yang memadai.

$\begin{array}{rrr}\text { Musik } & \begin{array}{r}\text { membuat } \\ \text { kemampuan }\end{array} & \text { untuk }\end{array}$
berkolaborasi, saling mendengar dan menyimak, mengambil resiko, berkomunikasi dengan jelas dan mengembangkan tanggung jawab individual dan sikap profesional. Musik dapat mewujudkan rasa kebersamaan dan saling memiliki yang merupakan suatu dorongan yang positif dalam kehidupan bersosialisasi. Karena pendidikan musik terdiri dari kegiatan praktik dan teori maka proses kegiatan musik dapat mengembangkan keahlian berkreasi, berpikir analisis dan kritis, berkomunikasi, berkonsentrai, disiplin, berimajinasi bahkan pendidikan musik yang baik dan benar meliputi berbagai aspek yang luas dalam kehidupan manusia.

Untuk memperoleh manfaat yang optimal bagi anak, dibutuhkan kegiatan musik secara langsung. Jamalu (1988:2) 
mengemukakan pengalaman musik ialah penghayatan suatu musik melalui kegiatan mendengarkan, bernyanyi, bermain musik, bergerak mengikuti musik, membaca musik, sehingga peserta didik mendapat gambaran menyeluruh tentang ungkapan musik.

Pengalaman musik diperlukan untuk mengembangkan kemampuan dasar musik anak. Beberapa kemampuan mendasar yang dapat ditingkatkan melalui musik menurut Kamtini dan Tanjung (2005: 103) adalah kemampuan mendengar, memeragakan dan berkreativitas. Pertama, kemampuan mendengar adalah kemampuan yang sangat esensial.

Musik mengkomunikasikan pesan. Pesan akan diterima dengan baik, apabila pesan dapat didengar, ditangkap atau dirasakan dengan baik. Oleh karena itu kegiatan mendengar hendaknya dipentingkan seperti memperlakukan unsur musik yang lain. Kegiatan mendengar gunanya untuk meningkatkan ketrampilan mendengar secara diskriminatif. Menurut Mahmud (1995: 51) kegiatan mendengar bertujuan: (a) menghayati peran birama, dan pola irama dalam membangun suasana hati; (b) meningkatkan kepekaan terhadap isi dan pesan yang diungkapkan oleh irama atau melodi, musik atau lagu pada umumnya; (c) menghayati ungkapan musik melalui pengamatan terhadap instansi dinamik, tempo atau perubahan gaya; (d) meningkatkan kemampuan mendengar untuk berolah musik dengan baik.

Kedua, kemampuan memperagakan dikembangkan antara lain dengan cara bernyanyi dengan tinggi nada yang murni dan tepat dan memainkan berbagai irama iringan, dalam berbagai tanda birama. Selain itu, peningkatan kepekaan terhadap isi dan pesan musik atau lagu dapat dilakukan melalui bernyanyi ataupun melalui asambel alat musik perkusi sederhana. Menurut Mahmud (1995: 51) kegiatan memeragakan bertujuan: (a) meningkatkan ketrampilan bernyanyi dengan baik dan benar; (b) mengungkapkan musik atau lagu dengan gerak jasmaniah; (c) meningkatkan kemampuan memilih dan memainkan alat musik perkusi untuk iringan.

Ketiga, kemampuan berkreativitas. Musik adalah aktivitas kreatif, seorang anak yang kreatif, antara lain tampak pada rasa ingin tahu, sikap suka mencoba dan daya imajinasinya, kemampuan berkreativitas adalah kemampuan menanggapi isi dan pesan musik atau lagu dengan perbuatan yang bersifat kreatif. Kegiatan berkreativitas bertujuan memantapkan dan mengembangkan pengetahuan dan ketrampilan musik yang telah diperoleh antara lain: (a) mencoba dan dapat memperoleh alat musik perkusi; (b) meningkatkan kemampuan mendengar musik; (c) meningkatkan kepekaan terhadap isi dan pesan.

Bentuk kegiatan musik yang utama di PAUD adalah bernyanyi. Menurut Kamtini dan Tanjung (2005: 118), bernyanyi adalah kegiatan musik yang fundamental, karena anak dapat mendengar melalui inderanya sendiri, menyuarakan tinggi-rendahnya nada dan irama musik dengan suaranya sendiri. Dengan mengajak anak bernyanyi, sama artinya dengan memberi anak pengalaman yang berharga dan menyenangkan. Jamalus (1988:2) mengemukakan pemberian 
pengalaman musik pada anak terutama melalui kegiatan bernyanyi.

Bernyanyi merupakan bagian yang penting dalam pengembangan diri anak (Jamalus, 1988: 46). Pendidik di PAUD harus mengarahkan anak didiknya bukan sebagai penyanyi, tetapi lebih pada bagaimana membuat anak-anak menjadi antusias dalam bernyanyi. Dengan bernyanyi, anak-anak dapat mengekspresikan apa yang dirasakan, dipikirkan, diimpikan secara pribadi dan melalui bernyanyi anak akan bersentuhan dengan sesuatu yang indah. Hal ini disebabkan karena bernyanyi juga berfungsi sebagai alat bagi anak untuk mengungkapkan pikiran dan perasaannya. Oleh sebab itu, kegiatan bernyanyi merupakan hal yang penting di PAUD. Menurut Mahmud (1995: 58), perolehan bernyanyi yang diharapkan adalah agar anak: (1) mendengar dan menikmati lagu; (2) mengalami rasa senang bernyanyi bersama; (3) mengungkapkan pikiran, perasaan dan suasana hatinya; (4) merasa senang bernyanyi dan belajar bagaimana mengendalikan suara; (5) menambah perbendaharaan lagu.

Pembelajaran musik bagi anak dapat mengembangkan kemampuan musikal dan mendorong anak memperoleh keterampilanketerampilan dasar musikal, sebagaimana dikemukakan Mahmud (1996: 149) kegiatan musik di PAUD bukan sekedar untuk membuat anak merasa senang. Dengan bimbingan yang simpatik dan bijaksana melalui kegiatan musik, guru dapat mendorong anak untuk memperoleh keterampilan-keterampilan dasar musikal dengan cara-cara informal serta dengan pengalaman langsung.Pendekatan semacam ini menghendaki persiapan tepat guna jika ingin berhasil.

Menstimulasi kepekaan musikal anak akan membantu anak mengembangkan citarasa keindahan (estetika), daya intelektual, sekaligus memberikan anak apresiasi musik yang luas dan dalam suasana ceria. Mahmud (1996: 149) menambahkan,

Seandainya tujuan pembelajaran musik adalah sekedar untuk kesenangan maka kita akan sampai pada suatu sikap, bahwa pendekatan apapun untuk berolah musik, semuanya dapat diterima. Apabila hal ini terjadi, maka tidak saja kita telah melangkah di atas jalan penuh bahaya bersama anakanak pada usianya kesempatan emas guna memperkaya dan memperluas pengalaman musik anak sebagaimana mestinya.

Dalam mengembangkan pengajaran musik di PAUD, ada dua hal dasar yang perlu diperhatikan oleh seorang pendidik, yaitu dasar kependidikan dan dasar teoritis. Menurut Kamtini dan Tanjung (2005: 108109), beberapa hal yang perlu dipertimbangkan dalam menyediakan bahan lagu atau musik sebagai dasar kependidikan, antara lain: Pertama, aspek psikologis. Isi lagu atau musik benar-benar sesuai dengan jiwa dan alam pikiran anak; Kedua, aspek fisik. Tenaga, kekuatan, kemampuan dan keterampilan anak masih terbatas. Organorgan tubuh seperti alat-alat pernapasan dan alat-alat suara masih dalam taraf pertumbuhan; Ketiga, aspek sosiologis. Penyediaan musik atau lagu tidak keluar dari lingkungan hidup anak: suka-duka dan pergaulan kanak-kanak sehari-hari, rasa kasih sayang dan sebagainya; Keempat, aspek paedagogis. Bahan musik yang 
disediakan dianggap dapat membantu perkembangan, pertumbuhan, kecerdasan dan keterampilan anak dalam segala hal menuju kedewasaan secara wajar; Kelima, aspek didaktis. Melodi harus sederhana. Langkah interval jangan terlalu sukar, sebaiknya jarak nada berdekatan tidak melampaui kuart. Ritme (rhythm) atau irama yang dipakai yang mudah saja, nada-nada yang digunakan cukup sampai nada 1/8.

Dasar teoretis pengajaran musik di PAUD, menurut Kamtini dan Tanjung (2005: 109-111), sebagai berikut: (1) Untuk tahap permulaan, wilayah suara anak diusahakan tidak melampaui c' - g'. Selanjutnya, secara bertahap proses latihan dapat dilakukan sampai oktaf ( $\left.c^{\prime}-c^{\prime}\right)$ dan seterusnya sampai d'; (2) Pada awal tahap belajar bernyanyi, anak melakukannya dengan cara menirukan lagu-lagu yang didengarnya, baik dari anggota keluarga, teman-teman, guru, radio maupun acara hiburan di televisi; (3) Gerak melodi yang cocok untuk anak PAUD, yaitu: (a) Gerak di tempat, (b) Gerak berpindah dengan melangkah naik-turun, (c) Gerak berpindah dengan lompatan kecil, naik atau turun, yakni dalam interval terts; (4) Irama atau ritme paling cocok menggunakan nada $1 / 8$; (5) Bermain alat musik sederhana yang diciptakan sendiri dari bahan yang ada dilingkungannya; (6) Untuk musik di PAUD kebanyakan bentuk tunggal dan bentuk biner. Jadi musik atau lagu untuk taman kanak-kanak biasanya pendek tetapi dengan ritme dan melodi yang menarik, lincah dan manis; (7) Anak PAUD belajar lagu dengan cara meniru dan pembiasaan.
Selain itu, perlu diketahui, diperhatikan, dan dipertimbangkan karakteristik suara dan musik anak yang sesuai dengan aspek-aspek perkembangannya. Anak usia PAUD belajar berbicara dan bernyanyi dengan cara meniru apa yang mereka dengar dan meresponsnya serta mengekspresikannya dengan cara mereka masing-masing.

Sesuai dengan karakter tersebut, maka materi musik yang sesuai untuk anak amat perlu diperhatikan. Menurut Pekerti (2008), karakteristik musik anak antara lain: (1) musik pendek, mudah diingat; (2) memiliki tema atau cerita, sehingga mudah dicerna dan diingat; (3) memiliki unsur yang menarik minat anak yakni yang lucu, gembira dan imajinatif; (4) interval nada yang tidak sulit dicapai atau melompat terlampau jauh untuk menyanyikan; (5) ritme yang tidak banyak berubah-ubah. Birama yang digunakan adalah birama 2, 4 dan 3; (6) anak suka pada perulangan; (7) memberi kesempatan bagi anak untuk merangsang gerak; (8) Jumlah nada tidak terlampau banyak. Untuk permainan awal dibatasi 2 atau 3 nada saja pada instrumen musik pukul; (9) memiliki unsur bermain dan komunikatif dan memberikan kesempatan melakukan improvisasi.

Dalam proses belajar bernyanyi, anak tidak hanya melakukan peniruan apa yang mereka dengar, tetapi juga mengelaborasi dan mengeksplorasi kemampuan mekanisme vokalnya. Berdasarkan karakteristik suara dan musik anak yang dikemukakan di atas, dapat ditentukan karakteristik lagu-lagu yang sesuai digunakan pada proses pembelajaran musik di PAUD. 
Dalam memilih lagu bagi anak usia PAUD, ada beberapa hal yang perlu diperhatikan. Menurut Palmer seperti dikutip Rachmi (2008: 2.16), lagu yang dipilih untuk anak-anak prasekolah adalah lagu yang : (1) dapat mendorong anak untuk aktif terlibat dalam kegiatan yang diselenggarakan pendidik; (2) berhubungan dengan minat anak-anak; (3) berhubungan dengan dunia anak-anak; (4) memiliki melodi yang berisi frase-frase yang diulangulang sehingga mudah dipelajari dan diingat oleh anak-anak; (5) menekankan pada unsur-unsur ritmik, irama, dan aliterasi; (6) bila berupa rekaman dari berbagai versi lagu atau musik instrumentalia yang liriknya mudah untuk diganti dengan lirik yang baru ciptaan pendidik dan peserta didik; (7) anakanak dapat diminta untuk menggantikan namanya sendiri, atau teman-temannya, atau saudara-saudaranya bila lagu tersebut menyebutkan nama orang.

Bernyanyi adalah kegiatan musik yang fundamental, karena anak dapat mendengar melalui inderanya sendiri; menyuarakan beragam tinggi nada dan irama dengan suaranya sendiri. Dengan mengajak anak bernyanyi bersama, kita memberi anak pengalaman yang berharga lagi menyenangkan, yang dilakukan bersama-sama. Adapun perolehan bernyanyi yang diharapkan, adalah agar anak: (1) mendengar dan menikmati lagu; (2) mengalami rasa senang bernyanyi bersama; (3) mengungkapkan pikiran, perasaan, dan suasana hatinya; (4) merasa senang bernyanyi, dan anak dapat belajar bagaimana mengendalikan suara; menambah perbendaharaan lagu.
Anak bernyanyi menurut cara dan gayanya sendiri, karena ia menyenanginya. Benar, kita dapat menyuruh anak bernyanyi dengan cara lain, yang menurut pendapat kita hasilnya akan lebih baik, umpamanya menyuruh anak melakukan latihan vokal dengan paksa, atau dengan latihan yang melelahkan. Maksudnya agar anak dapat meningkatkan mutu suaranya. Namun cara ini kurang bijak, karena dapat mengurangi rasa senang, rasa gembira anak bernyanyi. Akibatnya, bisa-bisa anak kurang menyukai musik, atau bernyanyi.

Karena bernyanyi memegang peran sangat penting dalam proses pembelajaran di PAUD, maka guru dituntut memiliki kemampuan Stimulasi Motorik Kasar sederhana yang akan diajarkan kepada peserta didik.

\section{Hubungan Musik dengan Pengembangan Motorik Kasar Anak Usia Dini}

Pada masa usia dini merupakan masa terjadinya kematangan fungsi-fungsi fisik dan psikis yang siap merespon stimulasi (rangsangan) yang diberikan oleh lingkungan. Masa ini merupakan masa untuk meletakkan dasar pertama dalam mengembangkan potensi fisik (motorik), intelektual, emosional, sosial, bahasa, seni dan moral spiritual. Kegiatan gerak dan lagu sangat melekat erat dan tidak dapat dipisahkan terutama dalam memberikan pembelajaran kepada anak usia dini. Pembelajaran gerak melalui lagu merupakan sebuah kegiatan dalam bermain sambil belajar dan belajar sambil bermain, aktivitas yang dilakukan melalui gerak dan lagu diharapkan akan menyenangkan anak sekaligus menyentuh perkembangan 
bahasa, kepekaan akan irama musik, perkembangan motorik, rasa percaya diri, serta keberanian mengambil resiko. Karena itu perlu adanya suatu kegiatan yang dapat melatih para pendidik anak usia dini dalam memberikan perangsangan pada anak melalui gerak melalui lagu. Ada mereka dengan memamerkan gerak-gerak non keseharian, antara lain, dengan spontanitas lenggak-lenggoknya seiring dengan keteraturan "musik" yang kita lantunkan. Atau bila seorang anak mendapatkan sesuatu yang menjadi idaman dan impiannya sepanjang hari, maka seiring dengan diraihnya impian tersebut, si anak pasti akan menarinari.Dengan alasan tersebut begitu pentingnya pembelajaran gerak melalui lagu bagi anak usiadini dalam melatih ketajaman pendengaran dan daya konsentrasi anak terutama pada aspek kecerdasan emosional, kecerdasan musikal dan kecerdasan kinestetik.motorik kasar, dan motorik halus, untuk meningkatkan / mengembangkan kemampuan mengolah, mengontrol gerakan tubuh, meningkatkan keterampilan serta cara hidup sehat sehingga menunjang pertumbuhan jasmani yang sehat, kuat dan terampil.

Menurut EV. Andreas Christanday Musik sangat mempengaruhi manusia. Ia mengemukakan bahwa Beat (irama) mempengaruhi tubuh, ritme mempengaruhi jiwa, sedangkan harmoni mempengaruhi jiwa. Sementara apabila hati sedang susah, mencoba mendengarkan musik yang indah, yang memiliki irama (ritme) yang teratur. Perasaan akan menjadi lebih enak dan enteng. Bahkan di luar negeri, pihak rumah sakit banyak memperdengarkan lagu-lagu indah untuk membantu penyembuhan para pasiennya. Inilah bukti bahwa ritme mempengaruhi jiwa manusia.

Menurut John M. Ortiz dalam bukunya Nurturing Your Child With Music (2002: 117), ada beberapa pendekatan serta latihan yang dapat dipertimbangkan para orang tua dalam menggunakan musik serta suara.

a. Meluangkan waktu untuk duduk bersama anak dan bergantian memilih lagu dengan pesan positif dan menggembirakan.

b. Meningkatkan latihan musik dengan memainkan lagu-lagu pilihan atau mengajak anak bernyanyi bersama.

c. Mengajak anak untuk menghadiri pertunjukan musik.

d. Membuat kebiasaan baru yaitu meminjam album musik klasik atau moden yang dipilih bersama anak.

e. Mendaftarkan anak ke kursus musik untuk alat musik yang disukai anak.

Kemampuan mengelola motrik kasar merupakan kemampuan seseorang untuk mongkoordinasikan otot-otot besar sehingga stimulasi lagu melalui gerak yang indah. Kepekaan akan rasa indah timbul melalui pengalaman yang dapat diperoleh dari menghayati musik. Kepekaan adalah unsur yang penting guna mengerahkan kepribadian dan meningkatkan kualitas hidup. Seseorang memiliki kepekaan yang tinggi atas perasaan 
mereka maka ia akan dapat mengambil keputusan-keputusan secara mantap dan membentuk kepribadian yang tangguh.

Sepanjang hari, keceriaan dan kekaguman akan musik dialami secara spontan oleh setiap orang, kelompokkelompok kecil, atau guru dan anak-anak bersama-sama (Young, 2002 : 296). Pagi hari, anak-anak dan para guru bersorak dalam lagu, menyanyikan lagu "Selamat Pagi" atau "Sorak-sorak Bergembira" memberi corak di sepanjang hari. Gerak melalui lagu adalah bagian penting dari awal pertemuan, pertengahan belajar dan juga pada akhir belajar. Para ahli saraf memastikan bahwa lagu, gerakan dan permainan dengan musik pada kanak-kanak merupakan salah satu aktivitas neurologis yang bagus untuk memperkenalkan pola bicara, keterampilan sensori-motor dan kemampuan gerak vital. Anak kecil sangat tertarik jika musik menggunakan lagu, gerak, emosi dan permainan (Carol Crees $2010: 2$ ).

Kegiatan gerak melalui lagu sangat melekat erat dan tidak dapat dipisahkan terutama dalam memberikan pembelajaran kepada anak usia dini. Pembelajaran gerak melalui lagu merupakan sebuah kegiatan dalam bermain sambil belajar dan belajar sambil bermain, aktivitas yang dilakukan melalui gerak melalui lagu diharapkan akan menyenangkan anak sekaligus menyentuh perkembangan bahasa, kepekaan akan irama musik, perkembangan motorik, rasa percaya diri, serta keberanian mengambil resiko. Karena itu perlu adanya suatu kegiatan yang dapat melatih para pendidik anak usia dini dalam memberikan perangsangan pada anak melalui gerak dan lagu. Pada anak-anak potensi kecerdasan ini dapat distimulus melalui menari, dan olah raga yang mempergunakan lagu dan instrumen musik. Anak yang kecerdasan musiknya tinggi mempunyai kepekaan mendengarkan nada dan ritme musik. Menyanyikan lagu untuk anak atau memperdengarkan musik pada saat bermain. Pemaparan terhadap musik secara lebih awal ternyata dapat memperkuat kaitan-kaitan antara sel-sel otak dan bahkan mungkin dapat mengarahkan pada pembentukan jalur-jalur ikatan baru di dalam otak yang tengah berkembang. Gerak melalui Lagu tidak hanya mengajarkan kepada anak kecerdasan musikal, tetapi sekaligus mengajarkan kecerdasan lainnya, seperti kecerdasan matematis, linguistik, interpersonal dan intrapersonal dan kecerdasan Kinestetik.Melalui pembelajaran gerak dan lagu dapat mengembangkan motorik kasar anak untuk menggunakan salah satu kemampuan mental dalam mengkoordinasikan gerakan tubuh. Kemampuan ini dapat dirangsang melalui gerakan tubuh, tarian dan olah raga yang berhubungan dengan koordinasi tubuh, keseimbangan, kekuatan, kelincahan dan koordinasi mata dengan tangan dan kaki

Dalam melakukan pelatihan menyanyikan Lagu Anak bagi Guruguru PAUD untuk menstimulasi motorik kasar di Kecamatan Canduang Kabupaten Agam ini, berbagai pihak dilibatkan untuk mencapai tujuan sebagaimana telah dijabarkan sebelumnya. Beberapa pihak yang dilibatkan dalam kegiatan ini, antara lain: unsur pimpinan dan pendidik di TK Darul Falah dan TK Bairurrahman dan unsur pimpinan dan pendidik di Kecamatan Canduang Kabupaten Agam, pendidik 


\section{Indra Yeni $^{1)^{*}}$, Irdhan Epria Dharma Putra ${ }^{2)}$, Vivi Anggraini ${ }^{3)}$}

PAUD, TK/RA dan yang sederajat, IGTKIPGRI Kec Kecamatan Canduang Kabupaten Agam, Jurusan Pendidikan Guru Pendidikan Anak Usia Dini (PGPAUD) Fakultas Ilmu Pendidikan Universitas Negeri Padang.

TK Darul Falah Kabupaten Agam merupakan lokasi tempat dilaksanakannya kegiatan mitra pertama dan Baiturrahman lokasi pelaksanaan di mitra ke-dua di Lasi Kabupaten Agam, sehingga unsur pimpinan, pendidik, dan pihak yang terkait dapat memantau secara langsung perkembangan guru-guru TK tersebut dan dibandingkan dengan guru- guru TK lainnya di Kecamatan Canduang Kabupaten Agam, untuk keperluan evaluasi internal dibidang seni.

Pendidik PAUD, TK/RA dan yang sederajat di Kecamatan Canduang Kabupaten Agam dapat memanfaatkan kegiatan ini untuk meningkatkan pengetahuan dan keterampilannya dibidang seni khususnya mencipta gerak melaluilagu anak. Sedangkan bagi IGTKI-PGRI, kegiatan ini dapat diprogramkan sebagai kegiatan tahunan dengan bekerjasama dengan instansi terkait yang relevan. Bagi Jurusan Pendidikan Guru Pendidikan Anak Usia Dini (PG-PAUD) Fakultas Ilmu Pendidikan Universitas Negeri Padang, kegiatan ini mendatangkan manfaat yang banyak bagi staf pengajar dalam menerapkan bidang keilmuannya di masyarakat sebagai bentuk kegiatan Tridharma Perguruan Tinggi

\section{SIMPULAN DAN SARAN}

Dengan memperhatikan pembahasan yang telah dikemukakan di atas, maka pada bagian ini dikemukakan kesimpulan dan saran yang akan merangkum semua hasil pelaksanaan kegiatan Pelatihan Stimulasi Motorik Kasar Anak melalui kegiatan menyanyi bagi Guru-guru PAUD di Kecamatan Canduang Kabupaten Agam.

$$
\text { Setelah membahas tentang }
$$
permasalahan, tujuan, manfaat, khalayak sasaran, pelaksanaan dan hasil kegiatan maka selanjutnya diperoleh kesimpulan sebagai berikut :

a. Kegiatan Pelatihan Stimulasi Motorik Kasar Anak melalui kegiatan menyanyi bagi Guru-guru PAUD di Kecamatan Canduang Kabupaten Agam adalah suatu pengabdian kepada masyarakat yang dilakukan oleh tim pelaksana dari Jurusan Pendidikan Guru Pendidikan Anak Usia Dini Fakultas Ilmu Pendidikan Universitas Negeri Padang.Kegiatan ini berupaya memberikan penyuluhan dan bimbingan tentang cara-cara atau langkah-langkah menstimulasi dan mengembangkan motorik kasar anak melalui kegiatan menyanyi. Kegiatan ini juga mengulas kembali tentang hal-hal yang bersifat teknis yang berhubungan dengan kegiatan menyanyi seperti cara-cara membaca notasi musik dan langkahlangkah mengajarkan lagu pada anak di PAUD.

b. Bertolak dari tujuan kegiatan ini, pendidik PAUD di Kecamatan Canduang Kabupaten Agam memiliki kemampuan mengajarkan lagu dan stimulasi motorik kasar melalui gerak yang sesuai dengan lagu yang dinyanyikan anak dibantu dengan iringan keyboard tunggal sebagai salah 
satu alternatif media untuk menstimulasi Motorik kasar anak.

c. Kegiatan pengabdian kepada masyarakat ini dilaksanakan selama dua periode semester akademik, yaitu dimulai dari Januari - Juni hingga semester July - Desember 2019, atau lebih kurang 7 (tujuh) bulan, mulai Maret 2019 sampai dengan November 2019. Pelatihan ini dilaksanakan dengan menggunakan metode ilmiah yakni: observasi, penyusunan usulan kegiatan, pelaksanaan kegiatan yang terdiri dari persiapan, pengurusan administrasi, kegiatan di lapangan, evakuasi dan dilanjutkan dengan penyusunan laporan akhir.

Berhubung karena keterbatasan waktu pelatihan, maka tidak semua jenis dan spesifikasi pelatihan dapat diberikan. Oleh sebab itu, untuk masa-masa yang akan datang, melalui Lembaga Pengabdian Masyarakat Universitas Negeri Padang dapat diteruskan kegiatan ini dengan kelanjutan materi. Disarankan kepada tim Lembaga Pengabdian Masyarakat Universitas Negeri Padang untuk dapat mengadakan monitoring untuk tindak lanjut dari kegiatan pengabdian ini dimasa mendatang terhadap kelemahan dan keberhasilan kegiatan yang telah dilaksanakan.

\section{DAFTAR PUSTAKA}

Abril, C. R. (2011). Music, movement, and learning. MENC Handbook of of Research on Music Learning: Applications, 2, 92-129

Arsyad, Azhar. 2007. Media pembelajaran. Jakarta: Grafindo.
Asyar, Rayandra. 2011. Kreatif Mengembangkan Media Pembelajaran. Jakarta: Gaung Persada (GP) Press.

Chirst, William dan Delone, Richard. 1975. Introduction to Material and Structur of Musik. New Jersey: Indiana University.

Daniyanto dan Steward. 2012. Langsung Jago Main Keyboard Otodidiak. Depok: Pustaka Makmur.

Departemen Pendidikan Nasional. 2003. Undang-undang Republik Indonesia Nomor20 Tahun 2003 tentang Sistem Pendidikan Nasional. Jakarta : Fokusmedia.

Djohan. 2009. Psikologi Musik. Yogyakarta: Best Publisher.

Elliot, David James. 1995. Musik Matters: A New Philosophy of Musik Education.London: Oxford University Press.

Hamalik, Oemar. 1989. Media Pendidikan. Bandung: Citra Aditya Bakti.

Harjana, Mangun. 2012. "Kreativitas Guru TK dalam Menciptakan Lagu untuk Anak Usia Dini di TK Amongsiwi Kabupaten Batang”. Laporan Penelitian. Semarang: Universitas Negeri Semarang.

Hendrie, Gerald dan Bray, Trevor. 1978. Introduction to musik. An Arts FoundationCourse Series. London: Open University Press.

Hurlock, Elizabeth B. dan Dhama, Agus (eds). 1997. Perkembangan Anak Jilid 1.Alih Bahasa: Meitasari Tjandrasa dan Muslichah Zarkasih. Jakarta: Erlangga.

Jamalus. 1998. Pengajaran Musik melalui Pengalaman Musik. Jakarta: P2LPPAUD. 
Departemen Pendidikan dan

Kebudayaan.

Kamtini, dan Tanjung, Husni Wardi. 2005. Bermain melalui Gerak dan Lagu diTaman KanakKanak. Jakarta: Departemen Pendidikan Nasional.

Kamien, Roger. 1998. Musik an Appreciations. Annotated Instructor's Edition.New York: McGraw-Hill Book Company.

Rose, C., \& Nicholl, M. (2011). Accelerated learning for the 21st century.(D. Ahimsa, Penerj.) Bandung: Nuansa. 